\title{
Physical Activity and Sleep Quality of Elderly During The COVID-19 Pandemic Period
}

\section{Vinanda Maria Prastica1, Latifa Aini Susumaningrum1 ${ }^{1}$, Hanny Rasni' ${ }^{1}$, Tantut Susanto ${ }^{1}$, Fahruddin Kurdi', Roro Dewi Qudsyiyah², Khoirun Nasikhin²}

1 Program Studi Sarjana Keperawatan, Fakultas Keperawatan, Universitas Jember

2 UPT Pelayanan Sosial Tresna Werdha (PSTW) Bondowoso

\begin{tabular}{|c|c|}
\hline Article Info & Abstract \\
\hline $\begin{array}{l}\text { Article History: } \\
\text { Submitted: July 23rd }, 2021 \\
\text { Accepted: August 30th, } 2021 \\
\text { Published: August 31 } 1^{\text {st }}, 2021 \\
\text { Keywords: } \\
\text { Physical activity; Sleep } \\
\text { Quality; Elderly; COVID-19 } \\
\text { pandemic }\end{array}$ & $\begin{array}{l}\text { COVID-19 pandemic has caused the changes on the physical activity of } \\
\text { elderly. Physical activity can affect the sleep quality of elderly. This research } \\
\text { aims to analyze the correlation between physical activity and quality of sleep } \\
\text { during the COVID-19 pandemic at UPT PSTW Bondowoso. This research } \\
\text { uses a cross sectional study design. There are } 44 \text { samples of elderlies using } \\
\text { consecutive sampling. The instrument of this research is the characteristics } \\
\text { of the elderly questionnaire. The elderly's physical activity instrument uses } \\
\text { the Physical Activity Scale for Elderly (PASE) and the elderly's sleep quality } \\
\text { uses Pitssburgh Sleep Quality Index (PSQI). The analysis of research data } \\
\text { uses Spearman-rho (p-value }<0.05 \text { ). The results show that on physical } \\
\text { activity, the median result ( } 69.98 \text { ) and good sleep quality ( } 65.9 \% \text { ). The result } \\
\text { of the correlation test shows that there is a correlation between physical } \\
\text { activity and sleep quality ( } \mathrm{r}=-0,364 \text {; p }=0,015 \text { ). The conclusion of this } \\
\text { research, is that the important of physical activity in maintaining the quality } \\
\text { of sleep. Therefore, elderly should maintain physical activity to obtain a good } \\
\text { sleep quality. }\end{array}$ \\
\hline
\end{tabular}

\section{PENDAHULUAN}

Pandemi COVID-19 yang dimulai sejak tahun 2019 telah mengubah berbagai aspek kehidupan manusia, terutama pada lansia [1]. Kerentanan yang dialami oleh lansia pada masa pandemi COVID-19 disebabkan oleh penurunan daya tahan tubuh dan penyakit komorbid pada lansia. Masyarakat disarankan untuk mengurangi aktivitas di luar ruangan dan tetap berada di dalam rumah. Isolasi selama berbulan-bulan dapat menimbulkan kecemasan. Kecemasan menyebabkan pemrosesan kognitif yang cepat dan tanggapan motorik lebih cepat sehingga menimbulkan kurangnya kantuk pada lansia dan kualitas tidur yang buruk.

COVID-19 menjadi wabah penyakit yang menyebar dengan cepat di seluruh dunia . Indonesia melaporkan kasus pertama COVID-19 pada tanggal 2 Meret 2020, kasus paling banyak ditemukan pada rentang usia 45 sampai 54 tahun dan angka kematian tertinggi berada pada rentang usia sekitar 55 sampai 65 tahun. Bertambahnya angka

Corresponding author:

Vinanda Maria Prastica

vinadamr@gmail.com

Media Keperawatan Indonesia, Vol 4 No 3, August 2021

e-ISSN: 2615-1669

ISSN: 2722-2802

DOI: $10.26714 / \mathrm{mki} .4 .3 .2021 .191-200$ 
kasus COVID-19 di Indonesia, pemerintah mengharuskan masyarakat agar melakukan physical distancing. Semua kegiatan yang biasanya dilakukan di luar rumah, sekarang harus dilakukan di rumah selama masa pandemi COVID-19, seperti belajar, beribadah, dan bekerja harus tetap berada di dalam rumah. Masa-masa berlangsungnya physical distancing berdampak pada aspek kehidupan sehingga menyebabkan kecemasan dan kekhawatiran, terutama bagi lansia. Lansia yang diharuskan tetap berada di dalam tempat tinggalnya akan mengakibatkan kurangnya melakukan aktivitas fisik.

Perubahan tingkat aktivitas fisik selama pandemi COVID-19 yang sedemikian rupa dapat berisiko meningkatkan penyakit tidak menular [2]. Perhimpunan Dokter Spesialis Kedokteran Olahraga (PDSKO) merekomendasikan untuk tetap melakukan olahraga selama pandemi COVID-19 dengan intensitas sedang. Bentuk latihan bisa berupa latihan aerobik atau latihan kekuatan. Berolahraga atau melakukan aktivitas fisik lainnya dapat menjadi salah satu bagian pendukung untuk meningkatkan sistem imunitas tubuh yang dibutuhkan semua orang, terutama saat pandemi COVID-19. Mempertahankan aktivitas fisik secara teratur selama isolasi diri penting untuk pencegahan kondisi kesehatan kronis di masa mendatang. Selain itu, meningkatkan aktivitas fisik pada lansia dapat mengatasi masalah kognitif pada lansia sehingga dapat mengurangi permasalahan yang terjadi pada lansia. Semua bentuk aktivitas fisik memiliki manfaat tersendiri, dianjurkan untuk mengurangi waktu duduk yang lama dan kurangi sedentary lifestyle dengan istirahat singkat di siang hari. Durasi aktivitas fisik lansia minimal 150 menit dengan tingkat intensitas sedang atau 75 menit dengan intensitas berat per minggu.

Kualitas tidur merupakan ukuran dimana seseorang dapat kemudahan dalam mengawali dan mempertahankan tidur. Kualitas tidur dapat dilihat dari durasi tidur dan keluhan yang dirasakan pada saat tidur atau setelah bangun tidur. Kualitas tidur pada lansia saat malam hari mengalami penurunan sekitar $70-80 \%$ dari usia dewasa [3]. Kondisi COVID-19 cenderung memberi dampak negatif dalam beberapa faktor yang memengaruhi kualitas tidur seseorang karena banyak perubahan yang terjadi dalam rutinitas sehari-hari, hidup dalam ketidakpastian, rasa takut akan kesehatan, rasa khawatir akan situasi dan pandemi COVID-19 yang berkepanjangan, isolasi mandiri dirumah, serta berkurangnya interaksi sosial antar individu.

Menurut Kementerian Kesehatan Republik Indonesia (2020) terkait dengan pencegahan penularan COVID-19 kepada lansia, terdapat larangan untuk berkunjung ke nursing home. Nursing home (rehabilitasi berbasis institusi) atau yang biasa disebut Pelayanan Sosial Tresna Werdha (PSTW) adalah tempat berkumpulnya orang-orang yang sangat rentan terhadap virus. Hanya orang-orang sehat dan tidak ada riwayat terpapar dengan lingkungan yang berisiko penularan yang dapat menemui atau mendampingi lansia. Di tengah pandemi COVID-19 pelayanan yang diberikan oleh pihak Pelayanan Sosial Tresna Werdha (PSTW) kepada lansia perlu ditingkatkan seperti berjemur dipagi hari, memfasilitasi dan mempertahankan komunikasi lansia dengan anggota keluarga melalui berbagai media, dan membatasi pengunjung serta interaksi langsung dengan lansia. Hal tersebut dilakukan mengingat lansia rentan terhadap penyakit. Tujuan umum penelitian ini untuk mengetahui ada tidaknya hubungan antara aktivitas fisik dengan kualitas tidur pada lansia di masa pandemi COVID-19 di UPT Pelayanan Sosial Tresna Werdha (PSTW) Bondowoso. Hasil penelitian ini diharapkan dapat menjadi sumber informasi mengenai hubungan aktvitas fisik dengan kualitas tidur lansia sehingga dapat meningkatkan aktivitas fisik sesuai dengan kemampuan lansia dan mendapat kualitas tidur yang baik. 


\section{METODE}

Desain penelitian yang digunakan pada penelitian ini adalah desain penelitian observasional analitik Cross Sectional. Variabel yang diteliti yaitu aktivitas fisik dan kualitas tidur. Populasi pada penelitian ini adalah 100 lansia yang tinggal di UPT Pelayanan Sosial Tresna Werdha (PSTW) Bondowoso. Sampel pada penelitian ini adalah lansia yang masuk pada kriteria inklusi dan eksklusi sejumlah 44 responden. Pengambilan sampel dengan teknik consecutive sampling.

Tahapan awal atau persiapan melakukan izin etik penelitian di Fakultas Keperawatan Universitas Jember dan mengajukan surat perizinan penelitian kepada instansi Fakultas Keperawatan UNEJ, LP2M, BAKESBANGPOL Provinsi Jawa Timur, Dinas Sosial Provinsi Jawa Timur yang ditujukkan kepada UPT Pelayanan Sosial Tresna Werdha (PSTW) Bondowoso. Peneliti menentukan populasi, sampel, dan responden yang akan digunakan untuk penelitian sesuai dengan kriteria inklusi dan kriteria eksklusi yang telah ditentukan oleh peneliti, kemudian responden didampingi oleh pihak tim peneliti dalam menandatangani lembar persetujuan untuk menjadi responden, sebelum itu tim peneliti membacakan lembar informasi yang ada secara jelas kepada responden. Tahapan selanjutnya adalah Universal Precaution (tindakan pengendalian infeksi tenaga kesehatan), tim peneliti mencuci tangan enam langkah dan menggunakan sabun, menggunakan APD level 1 yaitu masker medis, face shield, sarung tangan, baju kerja dan alas kaki khusus. Setiap lansia diberikan APD masker medis dan dianjurkan untuk mencuci tangan menggunakan sabun atau memakai hand sanitizer. Uji inter-rater reliability dilakukan pada penelitian ini untuk menyamakan persepsi antar anggota tim peneliti dalam proses pengumpulan data dengan menggunakan uji statistik Intraclass Correlation Coefficient (ICC).
Tahapan selanjutnya yaitu pengumpulan data, pelaksanaan peneliti dan pengumpulan data dilakukan di setiap kamar lansia oleh tim peneliti. Setiap lansia dan tim peneliti dihimbau untuk saling menjaga jarak minimal satu meter dan tidak bersentuhan dan bersalaman. Tim peneliti membagikan kuesioner penelitian dan ballpoint kepada setiap lansia. Mengukur variabel independen yaitu aktivitas fisik dengan memberikan kuesioner Physical Activity Scale for Elderly (PASE) dan variabel dependen kualitas tidur dengan memberikan kuesioner Pittsburgh Sleep Quality Index (PSQI). Pengisisian kuesioner oleh responden didampingi oleh tim peneliti. Tim peneliti mengumpulkan kembali kuesioner setelah diisi oleh responden dan dilakukan pengecekan kembali terkait kelengkapan kuesioner oleh tim peneliti. Kegiatan pengumpulan data berakhir, lansia dapat mencuci tangan menggunakan sabun atau menggunakan hand sanitizer kembali. Dilakukan desinfeksi ruangan oleh pihak UPT Pelayanan Sosial Tresna Werdha (PSTW) Bondowoso

Analisis data dengan analisis univariat dan analisis bivariat. Analisis bivariat menggunakan jenis data variabel independen dan variabel dependen, pada penelitian ini yaitu numerik dan kategorik, sehingga untuk uji statistik yang digunakan yaitu uji Spearman-rho dengan tingkat kemaknaan $\mathrm{p}<0,05$.

Penelitian ini dilakukan sesuai dengan etika penelitian yang meliputi lembar persetujuan (informed consent), kerahasiaan (confidentiality), keadilan (justice) dan kemanfaatan (beneficiency).

\section{HASIL}

Hasil penelitian menunjukkan bahwa lansia menurut usia memiliki nilai tengah 68 tahun. Jenis kelamin lansia di dominasi oleh perempuan $29(65,9 \%)$. Tingkat pendidikan lansia sebagian besar yaitu lulusan Sekolah Dasar (SD)/Sederajat 20 (45,5\%). Respon 
terhadap penyakit pada lansia sebagian besar tidak sakit $31 \quad(70,5 \%)$ dan lingkungan fisik dalam kategori baik $27(61,4 \%)$.

Hasil penelitian menunjukkan bahwa aktivitas fisik pada lansia di masa pandemi COVID-19 di UPT Pelayanan Sosial Tresna Werdha (PSTW) Bondowoso diperoleh nilai tengah sebesar 69,98 jam per minggu.

Hasil penelitian menunjukkan bahwa kualitas tidur pada lansia di masa pandemi COVID-19 di UPT PSTW Bondowoso lebih banyak memiliki memiliki kualitas tidur yang baik $29(65,9 \%)$ dan kualitas tidur buruk $15(34,1 \%)$.

Analisa hubungan aktivitas fisik dengan kualitas tidur pada lansia di masa pandemi COVID-19 di UPT Pelayanan Sosial Tresna Werdha (PSTW) Bondowoso tahun 2021 dilakukan dengan menggunakan uji
Spearman-rho. Berdasarkan hasil uji Spearman-rho menunjukkan terdapat hubungan antara aktivitas fisik dengan kualitas tidur pada lansia $(\mathrm{r}=-0,364 ; p$ value $=0,015)$. Hasil perhitungan nilai $r$ menunjukkan -0,364 yang berarti terdapat hubungan antara kedua variabel dengan kekuatan lemah. Arah hubungan menunjukkan nilai yang negatif berarti semakin terpenuhi kebutuhan aktivitas fisik, maka akan semakin terpenuhi kualitas tidur pada lansia. Lebih lanjut, nilai $\mathrm{R}^{2}=0,021$ yang berarti kualitas tidur lansia 2,1\% ditentukan dari nilai aktivitas fisik yang dilakukan. Berdasarkan persamaan $\mathrm{y}=6,16-7,12 \mathrm{E}-3^{*} \mathrm{x}$, dimana $\mathrm{y}=$ kualitas tidur dan $\mathrm{x}=$ aktivitas fisik. Misalkan jika nilai aktivitas fisik $(\mathrm{x})=1$, maka kualitas tidur (y) $=6,16-7,12^{*} 10^{\wedge}-3^{*} 1=6,15$. Jadi kualitas tidur lansia termasuk dalam kategori kualitas tidur buruk.

Tabel 1

Karakteristik responden $(n=44)$

\begin{tabular}{lc}
\hline \multicolumn{1}{c}{ Karakteristik Lansia } & $\mathrm{n}(\%)$ \\
\hline Usia (tahun) & \\
Md ( $\left.\mathrm{P}_{25}-\mathrm{P}_{75}\right)$ & $68(65-76)$ \\
\hline Jenis Kelamin & $15(34,1 \%)$ \\
Laki-laki & $29(65,9 \%)$ \\
Perempuan & \\
\hline Tingkat pendidikan & $10(22,7 \%)$ \\
Tidak Sekolah & $20(45,5 \%)$ \\
SD/Sederajat & $7(15,9 \%)$ \\
SLTP/Sederajat & $6(13,6 \%)$ \\
SLTA/Sederajat & $1(2,3 \%)$ \\
Perguruan Tinggi & \\
\hline Respon Terhadap Penyakit & $13(29,5 \%)$ \\
Sakit & $31(70,5 \%)$ \\
Tidak sakit & \\
\hline Lingkungan Fisik & $17(38,6 \%)$ \\
Lingkungan fisik kurang & $27(61,4 \%)$ \\
\hline Lingkungan fisik baik &
\end{tabular}


Tabel 2

Aktivitas fisik pada lansia di masa pandemi COVID-19 ( $\mathrm{n}=44)$

\begin{tabular}{lccc}
\hline \multicolumn{1}{c}{ Indikator Aktivitas Fisik } & Md (P25-P75) (Jam per Minggu) & $\mathrm{Z}$ & $p$-value \\
\hline Aktivitas diwaktu luang & $19,68(13,14-43,67)$ & 0,232 & $<0,001$ \\
Aktivitas rumah tangga & $50(46,25-70)$ & 0,318 & $<0,001$ \\
Aktivitas sukarela & $0(0-0)$ & 0,532 & $<0,001$ \\
\hline Total & $69,98(57,74-106,56)$ & 0,212 & $<0,001$ \\
\hline
\end{tabular}

\section{Kualitas Tidur}

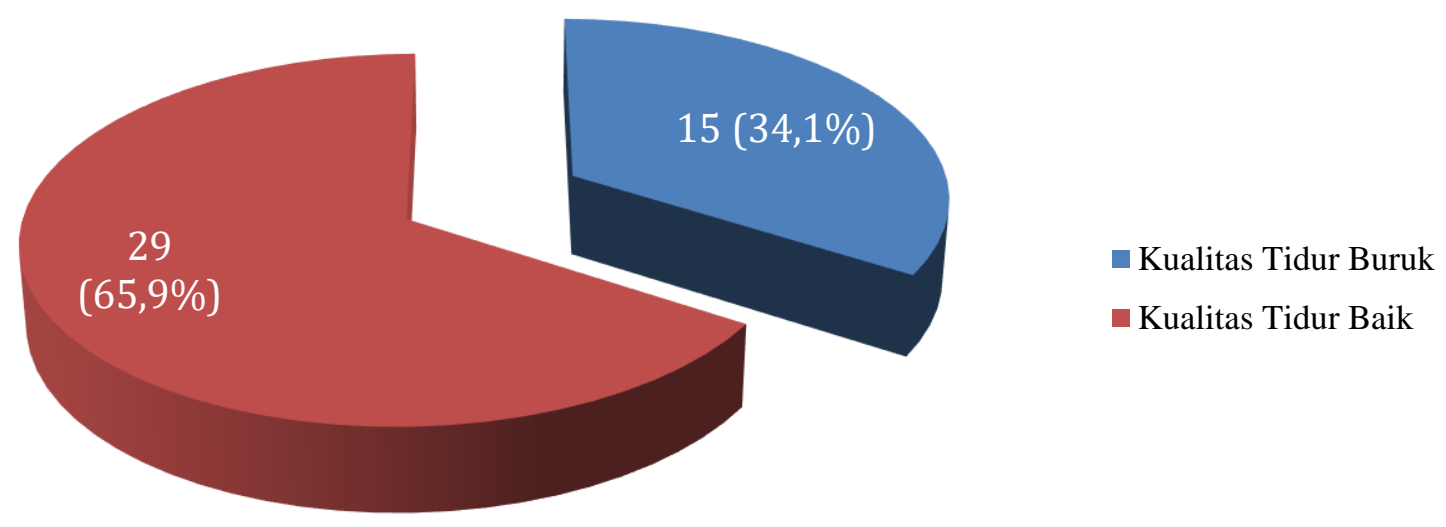

Gambar 1

Kualitas Tidur pada lansia di masa pandemi COVID-19 (n=44) 


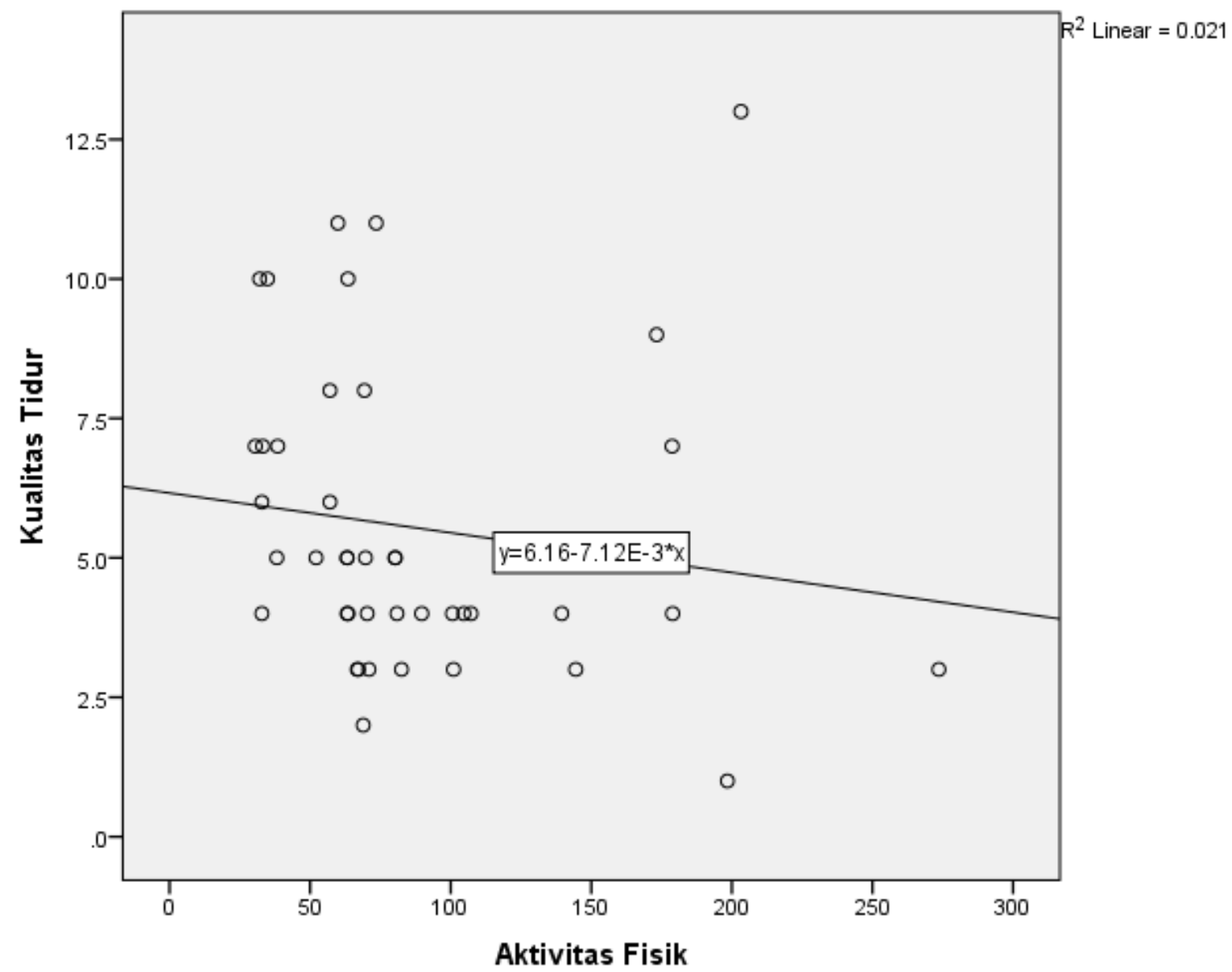

Gambar 2

Grafik Scatter Plot dan korelasi Spearman-rhoaktivitas fisik dengan kualitas tidur pada lansia di masa pandemi COVID-19

\section{PEMBAHASAN}

\section{Karakteristik responden}

Hasil penelitian ini menunjukkan lansia di UPT Pelayanan Sosial Tresna Werdha (PSTW) Bondowoso memiliki nilai tengah usia yaitu 68 tahun. Hasil penelitian lain menunjukkan bahwa 48,9\% lansia berada pada rentang usia 56-65 tahun [4]. Hasil penelitian yang mendukung yaitu penelitian yang dilakukan oleh Rudimin (2017) yang menyebutkan bahwa 42,9\% lansia berada pada kisaran usia 68-72 tahun. Penelitian yang dilakukan oleh Dahroni (2017) bahwa $52,7 \%$ lansia berada pada kisaran usia $>70$ tahun. Kholifah (2016) menjelaskan bahwa lansia didefinisikan sebagai seseorang yang telah berusia lebih dari 60 tahun, dimana proses menua merupakan proses yang bertahap sehingga mengakibatkan perubahan komulatif, baik perubahan fisik, psikologis, dan sosial. Perubahan yang dialami lansia dapat menyebabkan konsekuensi fungsional. Konsekuensi fungsional merupakan akibat dari faktor risiko, perubahan fisik, serta perilaku individu atau lansia sendiri sehingga menyebabkan munculnya suatu efek yang dapat diamati dan berpengaruh terhadap kehidupan sehari-hari.

Berdasarkan hasil penelitian disebutkan bahwa $29(65,9 \%)$ lansia di UPT Pelayanan Sosial Tresna Werdha (PSTW) Bondowoso berjenis kelamin perempuan. Hasil penelitian yang dilakukan oleh Laili \& Hatmanti (2018) menyebutkan bahwa 69,5\% lansia berjenis kelamin perempuan. Penelitian lain yang dilakukan Dahroni 
(2017) menyebutkan bahwa 81,1\% lansia berjenis kelamin perempuan. Sementara itu 61,1\% lansia berjenis kelamin perempuan dikemukakan dalam penelitian yang dilakukan oleh Rudimin (2017) Perbedaan jenis kelamin dalam seseorang erat kaitannya dengan perubahan fisik, psikologis maupun sosial dalam kehidupannya. Perempuan akan mengalami fase menopouse dalam kehidupannya, fase menopouse pada perempuan menyebabkan seorang perempuan lebih rentan mengalami penyakit degeneratif seperti penyakit kardiovaskuler, sebagaimana disebutkan dalam penelitian yang dilakukan oleh Xavier (2017) yang menyebutkan bahwa 93,3\% penderita hipertensi adalah perempuan. Memasuki usia lebih dari 55 tahun perempuan mempunyai risiko lebih tinggi untuk menderita hipertensi. Perbedaan hormon kedua jenis kelamin merupakan salah satu penyebab terjadinya pola tersebut. Produksi hormon estrogen menurun saat menopause sehingga tekanan darah meningkat.

Hasil penelitian menunjukkan bahwa mayoritas lansia di UPT Pelayanan Sosial Tresna Werdha (PSTW) Bondowoso berpendidikan SD sebanyak 20 (45,5\%). Penelitian yang dilakukan oleh Riyanti \& Ratnawati (2015) menyebutkan bahwa sebayak 63,5\% lansia memiliki tingkat pendidikan rendah. Sementara penelitian yang dilakukan oleh Berthiana \& Kasuma (2020) menjelaskan bahwa sebayak 45,5\% lansia yang menderita DM tipe 2 memiliki tingkat pendidikan SMA. Penelitian lain yang mendukung yaitu penelitian yang dilakukan oleh Guslinda (2020) menyebutkan bahwa 90\% lansia memiliki pengetahuan yang rendah terhadap COVID19. Tingkat pengetahuan yang tinggi didukung dengan tingkat pendidikan yang cukup layak. Diharapkan semakin tinggi pendidikan seseorang maka akan semakin mudah untuk mendapatkan akses informasi mengenai suatu permasalahan dalam hal ini termasuk permasalahan kesehatan. Memutus rantai dari penyebaran COVID-19 salah satu hal yang diperlukan ialah pengetahuan yang baik dari lansia.

Hasil penelitian menunjukkan bahwa sebagian besar lansia di UPT Pelayanan Sosial Tresna Werdha (PSTW) Bondowoso memiliki respon terhadap penyakit yaitu tidak sakit sebanyak 31 (70,5\%). Hasil penelitian menunjukkan bahwa separuh lebih $(65,9 \%)$ lansia dengan kualitas tidur yang baik termasuk lansia sakit yang tidak mengeluhkan banyak gejala penyakit. Hasil penelitian didukung oleh (Sakinah dkk, 2018) yang menyebutkan bahwa kualitas tidur pada penderita hipertensi di Puskesmas Rancaekek mayoritas buruk sebanyak 75 orang $(94,9 \%)$ dan hanya 4 orang $(5,1 \%)$ yang memiliki kualitas tidur baik. Hal tersebut terjadi dikarenakan derajat dan lama penyakit yang diderita lansia. Respon terhadap penyakit yang dimaksud pada penelitian ini adalah gangguan berupa perasaan sakit atau nyeri pada lansia.

Hasil penelitian menunjukkan bahwa sebagian besar lansia di UPT Pelayanan Sosial Tresna Werdha (PSTW) Bondowoso memiliki lingkungan fisik baik yaitu sebanyak 27 (61,4\%). Hasil penelitian yang didukung oleh (Candra dkk, 2019) yang menyebutkan bahwa 53,8\% lansia menjawab komponen nomor 5 mengenai faktor lingkungan mengatakan bahwa lingkungan sangat mempengaruhi kualitas tidur lansia. Lebih lanjut, penelitian yang dilakukan oleh (Moi dkk, 2019) menyebutkan bahwa sebanyak $63 \%$ lansia mengalami gangguan tidur kurang terganggu. Lansia yang kurang mengalami gangguan tidur salah satunya disebabkan oleh faktor deprivasi tidur yang dimaksud disini adalah lingkungan.

\section{Aktivitas fisik lansia di masa pandemi COVID-19}

Hasil penelitian yang dilakukan di UPT Pelayanan Sosial Tresna Werdha (PSTW) Bondowoso memperoleh nilai tengah aktivitas fisik sebesar 69,98 jam per minggu 
atau 10 jam per hari. Penelitian ini didukung oleh penelitian yang dilakukan oleh Dwijayanti (2021) yang menyebutkan bahwa selama masa pandemi COVID-19 dilakukan kegiatan senam aerobik selama dua kali dalam seminggu. Penelitian tersebut juga sejalan dengan penelitian yang dilakukan oleh Riyanti \& Ratnawati (2015) yang menyebutkan bahwa 60,3\% lansia melakukan aktivitas fisik secara mandiri. Memasuki usia lansia umumnya mulai dihadapi kondisi fisik yang bersifat patologis berganda (multiple pathology), misalnya tenaga dan energi berkurang, kulit keriput, gigi mudah lepas sendiri, tulang makin rapuh dan lain- lain. Secara umum kondisi fisik lansia mengalami penurunan secara berlipat ganda, sehingga menyebabkan gangguan atau kelainan fungsi fisik, psikologi, maupun sosial, keadaan tersebut dapat membuat lansia menjadi tergantung kepada orang lain untuk membantunya. Kondisi fisik yang bersifat patologis ini sebisa mungkin dapat dicegah dengan melakukan aktivitas fisik yang dapat ditoleransi oleh lansia.

Aktivitas fisik pada lansia sangat diperlukan mengingat aktivitas fisik yang teratur dapat meningkatkan kebugaran seseorang dan mencegah terjadinya gangguan fisik yang lebih parah pada lansia. Lansia yang rutin melakukan aktivitas fisik akan memperoleh banyak manfaat, salah satunya yaitu mempertahankan dan meningkatkan derajat kesehatan. Adapun pemenuhan aktivitas fisik seseorang dipengaruhi oleh beberapa faktor seperti usia, jenis kelamin, emosi, penyakit atau kelainan, dan kualitas tidur seseorang. WHO (2010) menetapkan pedoman tentang minimal aktivitas fisik yang harus dilakukan selama pandemi untuk menjaga kesehatan. Misalnya, individu dengan rentang usia antara 18-64 tahun, yang berdasarkan statistik merupakan kelompok usia rentan terinfeksi COVID-19, melakukan aktivitas fisik setidaknya minimal 150 menit untuk aktivitas sedang atau 75 menit untuk aktivitas berat. Hal tersebut menjadi bukti bahwa kegiatan aktivitas fisik dapat dilakukan oleh lansia. Pertambahan usia sering kali dikaitkan dengan perubahan fisik yang biasanya ditandai dengan penurunan fungsi suatu organ, dimana penurunan fungsi organ tersebut dapat menghambat seseorang melakukan aktivitas, terutama di masa pandemi COVID19. Pembatasan aktivitas selama pandemi COVID-19 mengharuskan seseorang melakukan physical distancing sehingga pemenuhan aktivitas seseorang harus tetap dilakukan sesuai dengan protokol kesehatan, terutama kelompok lansia yang merupakan kelompok yang rentan terpapar virus COVID-19.

\section{Kualitas tidur lansia di masa pandemi COVID-19}

Berdasarkan hasil gambaran kualitas tidur lansia, sebagian besar lansia dalam kategori baik sebanyak $29(65,9 \%)$ dan kualitas tidur lansia buruk sebanyak 15 (34,1\%). Penelitian yang sejalan dilakukan oleh Riyanti \& Ratnawati (2015) sebanyak $66,7 \%$ lansia yang tinggal di Panti Werdha memiliki kualitas tidur yang baik. Kualitas tidur didefinisikan sebagai suatu tolak ukur individu mendapat kepuasan terhadap tidurnya, sehingga memperlihatkan kesegaran saat bangun tidur dan tidak tampak perasaan gelisah atau bingung [3]. Penelitian yang dilakukan oleh Anggarwati \& Kuntarti (2016) menyebutkan bahwa $59,2 \%$ lansia rutin melakukan aktivitas fisik dalapat meningkatkan kualitas tidur, hal ini terjadi karena aktivitas fisik dapat meningkatkan relaksasi otot dan kebutuhan untuk istirahat. Senam lansia yang dilakukan secara rutin mampu meningkatkan sekresi enorfin, konsumsi energi, dan suhu tubuh yang dapat memudahkan tidur agar tubuh kembali pulih. Aliran darah yang lancar dapat membuat jalan oksigen terutama ke otak sehingga dapat mengontrol tekanan darah, hal ini mampu meningkatkan kenyamanan lansia saat tidur [13]. 


\section{Hubungan aktivitas fisik dengan kualitas tidur lansia di masa pandemi COVID-19}

Hasil penelitian yang dilakukan peneliti menunjukkan bahwa terdapat hubungan antara aktivitas fisik dengan kualitas tidur lansia pada masa pandemi COVID-19 di UPT Pelayanan Sosial Tresna Werdha (PSTW) Bondowoso dengan nilai $p$ value $=0,015, \mathrm{r}=$ $-0,364$. Kedua variabel ini memiliki korelasi semakin baik aktivitas fisik maka akan semakin baik kulitas tidur lansia, sebaliknya jika lansia melakukan aktivitas fisik yang kurang, maka akan semakin buruk pula kualitas tidur lansia, selain itu semakin berlebihan aktivitas fisik yang dilakukan maka semakin menurun kualitas tidurnya. Hasil penelitian ini sesuai dengan penelitian yang dilakukan oleh Laili \& Hatmanti (2018) yang menyebutkan terdapat hubungan antara aktivitas fisik dengan kualitas tidur pada lansia di Posyandu Lansia Wulan Erma Kelurahan Menanggal Surabaya. Penelitian tersebut juga sejalan dengan penelitian yang dilakukan oleh Fatkhurroji (2018) yang menyebutkan bahwa semakin aktif seorang lansia mengikuti senam aerobik maka akan semakin baik kualitas tidurnya. Hal tersebut terjadi karena lansia mengalami perubahan-perubahan fisik pada sistem muskuloskeletal.

\section{SIMPULAN}

Berdasarkan hasil penelitian dan pembahasan diatas dapat disimpulkan bahwa terdapat hubungan antara aktivitas fisik dengan kualitas tidur lansia di masa pandemi COVID-19 di UPT Pelayanan Sosial Tresna Werdha (PSTW) Bondowoso.

\section{UCAPAN TERIMAKASIH}

Peneliti mengucapkan terimakasih kepada seluruh responden yang telah bersedia untuk berpartisipasi dalam penelitian ini dan kepada semua pihak yang telah membantu serta mendukung peneliti selama proses penelitian.

\section{REFERENSI}

[1] Kementerian Kesehatan Republik Indonesia. Pedoman Pencegahan dan pengendalian Coronavirus Disease COVID-19. Jakarta: Direktorat Jenderal Pencegahan dan Pengendalian Penyakit (P2P); 2020.

[2] Ardella KB. Risiko Kesehatan Akibat Perubahan Pola Makan dan Tingkat Aktivitas Fisik Selama Pandemi COVID-19. J Med Hutama 2020;2:2927.

[3] Dahroni, Arisdiani T, Widiastuti YP. Hubungan antara Stress Emosi dengan Kualitas Tidur Lansia. J Keperawatan 2017;5:68-71.

[4] Fatkhurroji F, Munawaroh S, R. CH. Hubungan Senam Lansia dengan Kualitas Tidur Lansia di Posyandu Lestari Lansia Kelurahan Mojorejo, Kecamatan Taman, Kabupaten Madiun. Heal Sci J 2018;2:1-10.

[5] Rudimin, Harianto T, Rahayu W. Hubungan Tingkat Umur dengan Kualitas Tidur pada Lansia di Posyandu permadi kelurahan Tlogomas Kecamatan Lowokwaru Malang. Nurs News (Meriden) 2017;2:119-27.

[6] Kholifah SN. Keperawatan Gerontik. Jakarta: Kementrian Kesehatan Republik Indonesia; 2016.

[7] Laili FN, Hatmanti NM. Aktivitas Fisik dengan Kualitas Tidur Lansia di Posyandu Lansia Wulan Erma Menanggal surabaya. J Ilm Keperawatan 2018;4:7-14.

[8] Xavier EADC, Prastiwi S, Andinawati M. Hubungan Antara Aktifitas Fisik Dengan Tekanan Darah Pada Lansia Di Posyandu Lansia Desa Banjarejo Kecamatan Ngantang Kabupaten Malang. Nurs News (Meriden) 2017;2:343-51.

[9] Riyanti P, Ratnawati D. Hubungan Aktivitas, Status Emosional, dan Kualitas Tidur dengan Kualitas Hidup Lansia di Panti Werda Bina Bhakti Serpong Tangerang Tahun 2015. J Keperawatan Widya Gantari 2015;2:1-19.

[10] Berthiana, Kasuma WA. Hubungan Kualitas Tidur dengan Kualitas Hidup Lansia dengan Penyakit Diabetes Mellitus Tipe 2. Indones J Heal Sci 2020;12:11-6.

[11] Guslinda, Fridalni N, Minropa A. Faktor yang Berhubungan dengan Tingkat Kecemasan Lansia pada Masa Pandemi Covid 19. J Keperawatan 2020;12:1079-88.

[12] Dwijayanti K, Ferbrianti R, Pembangunan UT. Menjaga Daya Tahan Tubuh di Masa Pandemi Covid-19 dengan Senam Aerobik. BERNASJurnal Pengabdi Kpd Masy 2021;2:392-5. 

https://doi.org/10.31949/jb.v2i1.760.

[13] Anggarwati ESB, Kuntarti. Peningkatan Kualitas Tidur Lansia Wanita Melalui Kerutinan
Melakukan Senam Lansia. J Keperawatan Indones 2016;19:41-8. 